\title{
China - growth engine or obstacle for Asian developing economies?
}

\begin{abstract}
Over the last 30 years, changes in the East and Southeast Asian region have been fast and deep. China is the growth engine of a new regional production system which in turn has provoked changes in many other parts of the world. For its own fast growth, China has relied heavily on importing intermediate products from neighbouring countries, but this is changing with China now producing more of its own inputs and occupying also the more skill intensive parts of the value chain. Some countries in the region trade relatively little with China, but the trade itself may undermine long-term growth prospects. The paper analyses these trade impacts, distinguishing between groups of countries and products. It shows that China's growth augments opportunities for some but pulls others into a race to the bottom.
\end{abstract}

\section{Introduction 1}

Success commands attention. China has become the centre of global attention, because of its rapid growth. Thirty years of economic growth at a yearly average of $9 \%$ has lifted many millions of people out of poverty. Full explanations of this growth and transformation have yet to emerge, but the key factors seem clear:

- Internally it was the unlikely combination of the ideas of Adam Smith and the Chinese Communist Party. Adam Smith's central message was that economic development depends on the depth of the division of labour which in turn depends on the size of the market. China's internal market is big and it is growing fast with the removal of internal barriers and rising incomes. The depth of specialisation within China is little recognised but it is visible to visitors of its many industrial clusters. The contribution of the Chinese Communist Party lies in governing this market and controlling the transition to a new system. The party experimented with transitional institutions, which made it possible to move in stages from a society without private means of production to a capitalist society, and which made it possible to move gradually from a centrally planned to a market economy.
- Externally, the key explanatory factor lies in what one can call "China plus". The country's rapid success in global markets cannot be explained merely by reference to internal factors. One needs to consider China plus key neighbours; China plus Hong Kong and China plus multinational companies. To explain each in turn: First, the equipment and complicated components for many products "made in China" come from Japan, Korea, and Taiwan. Second, China's strength in transforming these inputs into final products is formidable but not sufficient; it was Hong Kong that provided the trade networks and logistics to link Chinese factories with their foreign customers. Third, China is able to move rapidly into producing more sophisticated products because multinational companies have established their factories - and in some cases also research and development departments - in the country.

This process of growth and structural transformation has been going on for three decades. Yet it is only recently that it has taken centre stage in the global debate on economic development. The reason is clear: China's rise has major external repercussions. Other Asian economies, notably Japan and South Korea, 
experienced periods of equally rapid growth, but their impact on the global economy was less dramatic because they were smaller and/or less outwardly oriented. While India is now also growing rapidly, its global footprint is much smaller. ${ }^{2}$ China's effects are so significant because three things come together: size, fast growth and openness. An economy that is so large, so open relative to its size (much more than the United States or the European Union) and that is growing at $9 \%$ per annum for nearly three decades is historically unprecedented.

The resulting "China effects" are felt throughout the world. There is concern in some parts of the world that China's expansion squeezes them out. In other parts of the world there is hope that China's rise will pull them up. Both the threats and opportunities are increasingly visible. Both competition and complementarity with China have significant effects on earning opportunities throughout the world.

In the following we concentrate on the implications of China's growth for other Asian countries, in particular the developing economies of Southeast and East Asia. ${ }^{3}$ The paper draws together and digests the available evidence. On many issues, however, good information and insights are lacking. We make these knowledge gaps explicit and set out the questions which future research needs to address.

\section{Differential trade impact}

It is now widely recognised that China's economy is closely tied in with the rest of the Asian economies, and particularly with Japan and East and Southeast Asia. In terms of direct impacts, China's imports are increasingly sourced from Asian economies, and Asia is also an important export market for Chinese products. However, trade relationships between China and the more advanced economies of the region are very different to those of the poorer countries, above all those in the Greater Mekong Subregion (GMS). ${ }^{4}$ This is seen clearly in Tab.1.

The four poorer GMS-countries all had substantial balance of trade deficits with China in 2005 (and deficits in earlier years as well), whereas six of the seven more advanced countries (in the bottom part of the table) had substantial trade surpluses. For the GMS countries, China was not a significant export market, accounting for between $1.9 \%$ and $7.5 \%$ of exports. It was, however, an important source of imported products, particularly for Myanmar and Vietnam. For the more developed economies, in contrast, China was an important export destination, accounting for between $8.2 \%$ and $28.8 \%$ of exports from these countries. 5

In addition to differences in the levels of trade with China between the GMS region and the higher-income economies of developing Asia,

Tab. 1: China's balance of trade with regional economies (US\$ mio.) 2005

\begin{tabular}{lrrrrrrr} 
Country & $\begin{array}{l}\text { Exports } \\
\text { to China }\end{array}$ & $\begin{array}{l}\text { Total } \\
\text { exports }\end{array}$ & \% China & $\begin{array}{l}\text { Imports } \\
\text { from China }\end{array}$ & $\begin{array}{l}\text { Total } \\
\text { imports }\end{array}$ & \% China & $\begin{array}{l}\text { Balance } \\
\text { of trade }\end{array}$ \\
\hline Cambodia & 25 & 2,857 & 0.9 & 590 & 4,095 & 14.4 & -565 \\
Laos* & 23 & 693 & 3.4 & 124 & 1,283 & 9.7 & -101 \\
Myanmar* & 250 & 3,648 & 6.8 & 1,068 & 3,616 & 29.5 & -819 \\
Vietnam & 2,318 & 30,801 & 7.5 & 7,618 & 30,076 & 25.3 & $-5,300$ \\
& & & & & & & \\
Indonesia & 7,664 & 92,909 & 8.2 & 9,207 & 64,377 & 14.3 & $-1,543$ \\
Malaysia* & 24,964 & 161,484 & 15.5 & 14,309 & 126,796 & 11.3 & 10,655 \\
Philippines* & 14,502 & 52,441 & 27.7 & 7,243 & 51,839 & 14.0 & 7,259 \\
South Korea* & 81,951 & 284,077 & 28.8 & 38,629 & 269,145 & 14.4 & 43,322 \\
Singapore* & 41,322 & 207,338 & 19.9 & 24,735 & 189,745 & 13.0 & 16,587 \\
Taiwan** & 34,036 & 198,435 & 17.2 & 20,094 & 182,616 & 11.0 & 13,942 \\
Thailand* & 15,241 & 110,107 & 8.3 & 11,155 & 118,191 & 9.4 & 4,086 \\
& & & & & & & \\
\hline
\end{tabular}

Notes: * Includes trade with Hong Kong where Hong Kong is in top ten partners; ** data only refers to trade with Hong Kong.

Source: Asian Development Bank, key indicators 2006, Internet: http://www.adb.org/Documents/Books/Key_Indicators/2006/default.asp. 
there are also clear differences in the types of products traded by these two groups of countries. For the seven more developed economies, manufactured goods (electrical and mechanical products, in particular) figure prominently. The exception is Indonesia, whose principal exports in 2005 were petroleum, plywood, rubber, shrimp and coffee (see Tab. 1). In the case of the GMS countries, the principal exports are natural resource-based, such as wood, rubber, timber, soya, pulses, rice and coffee. Taking the four principal exports from these four countries, a total of 16 items, the only manufacturing products that figure are textiles and garments, each cited once. Even Vietnam, which is rapidly increasing its exports of manufactures to the rest of the world, still exports raw materials to China and imports manufactured products, as highlighted by CHAPONNIÈRE et al. $(2007,12)$ : "Vietnam exports mainly raw products to China: oil, minerals; agricultural products, rubber, etc. In return, it imports mainly processed and manufactured products from China: refined oil, yarn and fabric used as input for its clothing industry, other intermediate products, machinery."

These figures certainly do not fully capture trade in the region. There is substantial illegal and unrecorded trade, which is discussed further below. Nevertheless, the contrast between the two groups of countries is clear. Although China has a reputation as an importer of raw materials and natural resources and an exporter of manufactured products, this is not actually the predominant pattern of intra-regional trade. China has hitherto been a substantial importer of manufactured goods from the more developed economies of the region.

\section{Primary products}

The new China depends heavily on imports of energy, raw materials and food. These imports have been rising rapidly and have been shown to have major implications for Africa and Latin America (KAPLINSKY et al. 2007; JENKINS/ DUSSEl PETERS 2007).

\section{Energy}

China's growth affects Asia (and the rest of the world) through its increasing demand for energy (see Tab. 2). China's energy consumption more than doubled between 1980 and 2000 . Energy consumption is being driven by rapid industrialisation, urbanisation and motorisation, and data for 2004 shows a further substantial rise (Internetsource: http://www. eia. doe.gov/oiaf/ieo/ieosector.html). China is not the only source of increasing energy consumption as Tab. 2 shows. The economies of India, Japan and South Korea, taken together, consumed roughly equivalent amounts of energy in 2000, and they have also shown substantial increases in energy consumption. Projections to 2030 show similar rates of expansion (Internetsource: http://www.eia.doe.gov/oiaf/ ieo/ ieosector.html).

China is, and will be, increasingly reliant on imports of energy. This has direct and indirect effects on other Asian economies. The indirect effects are threefold. First, China's demand for oil is a significant portion of the incremental increase in global oil consumption. If oil prices remain high, then some economies will benefit, including Vietnam as well as the West Asian economies, and natural gas exporters will also benefit. Net oil importers will lose out, with the biggest losers in Asia being Nepal and Pakistan. ${ }^{6}$

Second, there are distributional consequences within countries. Oil-based products account for a higher percentage of the spending of the poor, and the health impact on women of a switch from commercial fuels to biomass for heating and cooking is well-known. At the

Tab. 2: Total primary energy consumption in leading Asian economies

\begin{tabular}{lllll}
\multicolumn{2}{c}{ China } & \multicolumn{2}{c}{ India, Japan and South Korea } \\
\hline & Quadrillion Btu* & Index $(1980=100)$ & Quadrillion Btu & Index $(1980=100)$ \\
1980 & 17.5 & 100 & 21.1 & 100 \\
1990 & 27.0 & 156 & 30.2 & 144 \\
2000 & 38.8 & 225 & 43.9 & 207 \\
2004 & 59.6 & 340 & 47.0 & 223 \\
\hline
\end{tabular}

$*$ Btu $=$ British thermal units

Source: http://www.eia.doe.gov/emeu/international/energyconsumption.html 
same time, rising fuel costs may make it impossible to sustain the fuel subsidies that are widespread in Asia. This can cause political tensions, if governments can no longer sustain subsidies, as has been seen in Burma in 2007. Alternatively, a switch out of energy subsidies may actually benefit the poor if across-theboard subsidies, whose benefits mostly accrue to the non-poor, are replaced by targeted support for the poor. This was the policy chosen by the government of Indonesia (INDRAWATI 2006).

A third indirect effect of China's increasing consumption of energy relates to climate change. China is already the world's secondlargest producer of greenhouse gases, part of which arises from its high-sulphur coal (UMBACH 2005, 212). The level of energy that China requires in the future and the way in which this is generated will have substantial impacts on global climate change. The impact on global warming and climate change of the difference between a China that has a US energy profile in 2020, compared to a China with a European energy profile would be massive.

There are also direct effects. While most energy resources come from further afield in Asia - notably oil in West Asia and Central Asia, natural gas in these regions and also in Bangladesh, and hydropower in the Himalayan countries - the Greater Mekong Subregion also has considerable energy potential. The development of the enormous hydroelectric potential of Yunnan Province is a strategic goal of the Chinese government because it contributes to energy security and the economic development of the Southwest region of the country. This will have an impact on the various river systems, including, but not only the Mekong, that originate there. The Dulong (Irrawaddy), $\mathrm{Nu}$ (Salween), Lancang (Mekong), Yangtze, Pearl, Yuan and Lixian systems all originate or pass through Yunnan province. There is considerable debate on the impacts of new dams on these river systems.

At the same time, China is also encouraging investment by its neighbours in hydropower, the products of which might be exported to China. According to PeCH/Sunada (2006, 7 f.) "...China's electricity demand and its geopolitic position also drive the hydropower development and energy trade in other parts of the GMS. China has become active in promot- ing very active 'carrot' diplomacy through firm pledge for regional trade, readiness in providing financial support, and exporting the stateof-the-art hydropower development and investment to other Mekong countries such as Myanmar, Laos and Cambodia." The danger is that China's regional influence and financial power will commit smaller countries in the region to hydropower projects that are damaging to their own long-term development and are disadvantageous for the poor.

\section{Raw materials}

There is no overview which captures China's sourcing of raw materials for industrial production from Asian countries and the direct and indirect effects on these countries. However, the key issues can be set out by piecing together fragments of evidence from various sources. China's industrial development is broad-based and therefore requires many different types of raw materials. Imports of these products increase as rapidly growing domestic demand outstrips domestic supply and China's industrial development replaces imports of finished products by imports of raw materials (e.g. steel imports replaced by iron ore for domestic steel production). The rapid growth of China's industry and of its demand for imported raw materials has had a noticeable effect on international commodity prices, which have been rising fast in particular since the year 2000. China's demand has not been the only cause of these high prices but a significant contributor (GotTschalk/Prates 2006).

Take the example of metals. China's growth has been particularly fast in sectors that are big users of metal and other industrial commodities, such as automobiles, metallurgy and construction. This has increased demand for metals like steel, copper, aluminium and nickel ("The hungry dragon", The Economist, $19^{\text {th }}$ Feb 2004). China has increased its share of world demand for the main base metals from 7-10\% 1993 to $20-25 \%$ in 2003. Even allowing for a recent slow down in growth rates, China is likely to account for $30 \%$ of world demand by 2010 (Jim Lennon, Macquarie Bank Ltd, presentation at IDS, $1^{\text {st }}$ February 2006). The capacity to supply these raw materials is thought to lag behind demand for the next few years. As shown in Fig. 1, the commodity prices have increased substantially in recent years. This cycle of relatively high prices is expected to continue for the next few years. 
The benefits which suppliers derive from the high Chinese demand and the high prices, depend on who earns the rents, how these rents are utilised, and how sustainable the extraction is (GotTSCHAlK/ Prates 2006). These rents are not further analysed here because Asian countries are not major suppliers of metals to China. As metal importers they tend to suffer from the rising prices resulting from the high Chinese demand.

Whereas Latin America and Africa are the main suppliers of metals, with Asia playing only a minor role, Asian countries are major suppliers of timber to the world, in particular to China. Examining the wood industry is important because China's growth has a dramatic effect on the countries from which it sources. It is not a typical sector but it is a very important sector, in particular for South-East Asian countries. It is also a sector for which developmental consequences can be traced. Chinese import of forest products has grown fast: between
1997 and 2005, the value of forest product imports more than doubled, rising from $\$ 6.4$ billion to $\$ 16.4$ billion, and the volume more than tripled (White et al. 2006). This has three reasons:

- Internal consumption of timber, particularly for furniture and other wood-based products, has risen quickly. This is likely to continue because per capita consumption is still low and incomes are set to rise.

- Timber-based exports have grown fast over recent years. "The quantity of timber which is processed and exported is equivalent, in terms of volume, to over $70 \%$ of the timber imported by China“" (WhITE et al. 2006, 4). To some extent this is due to China displacing Asian competitors - by importing the raw material from the former furniture exporting country and out-competing it in the manufacturing process. One example is the displacement by China of exports of rubber-

Fig. 1: Price indices of metal commodities and oil (Index $2001=100)$

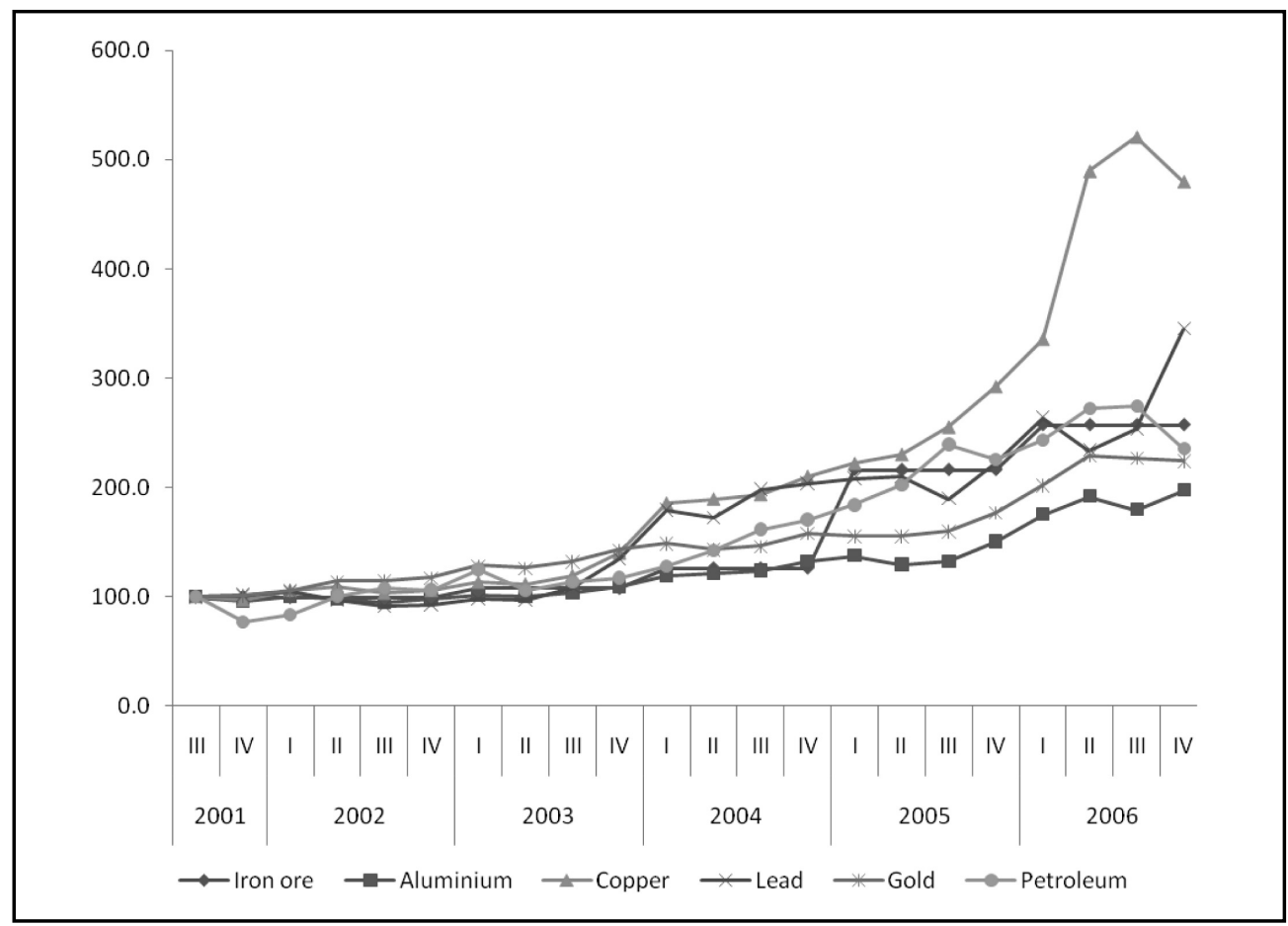

Source: derived from UNCTAD Handbook of Statistics On-line 2006-07; for the purposes of the figure above, average quarterly indices are calculated from monthly data 
wood furniture from Thailand to Japan (MITSUHASHI 2001).

- The internal capacity to provide raw material is not growing. After the devastating flooding along the Yangtze River in 1998, the Chinese government took drastic measures to protect its own forests. A ban on logging in state-owned forests in 1998 and the elimination of tariffs on log imports in 1999 led to a very rapid rise in round wood imports into China. The government has initiated a subsidised plantation programme but the domestic supply will at best slow down the growth of imports. Forest product imports are thought to double over the period 2006-2015 (WHITE et al. 2006).

While Russia is the biggest supplier of timber and timber products, the South East Asian countries are also major suppliers, notably Malaysia, Indonesia, Myanmar and Papua New Guinea. Taken together, countries in Pacific Asia are estimated to provide between 60 and $75 \%$ of timber products imported by China (WHITE et al. 2006, 5). Exact quantification is difficult because a large share comes from illegal felling and finds its way into China, often by using false documentation. Mirror statistics contrasting Indonesia's or Malaysia's exports and Chinese imports show substantial difference for trade in logs and sawn wood, but not for plywood or veneer (CHUNQUAN et al. 2004). It is likely that a large part of this difference is due to trade in illegal timber. PECH/SunADA (2006) suggest that $90 \%$ of logging is illegal in Cambodia, $50 \%$ in Myanmar, $45 \%$ in Laos, $40 \%$ in Thailand and 20$40 \%$ in Vietnam.

Myanmar is a particularly severe case both because of the extent of illegal trade and its political significance. Chinese recorded imports were 27 times the size of Myanmar's declared exports for 2000 (JOHNSON 2002), and this discrepancy gives some indication of the extent of illegal trade in 2000. This practice seems to continue. According to Global Witness (2005), cross border trade increased by $60 \%$ between 2001 and 2004 and over $90 \%$ of this trade is illegal. Much of the logging taking place in the country is financing the military regime or insurgent groups engaged in conflict. The situation has been compounded by the involvement of Thai and Chinese logging companies, with widespread and destructive logging occurring along the border with China (CHUNQUAN et al. 2004, 43).

According to some sources, China is now the world's leading importer of illegal timber, illegality defined as in conflict with either the letter of intent or intent of the law and or otherwise associated with corrupt practice (www.globaltimber.org.uk). The scale of such imports is hard to quantify, but there is little doubt that this trade has major repercussions for the exporting countries of Southeast Asia. While in principle exporting provides an opportunity for raising incomes, the unregulated nature of this trade turns this opportunity into a major problem for the exporting countries. Indeed, COXHEAD (2007) concludes from his analysis of China's booming demand for raw materials that the impact on Southeast Asian countries will depend on effective control of this trade by legal and economic measures. This seems to be agreed amongst all analysts.

The uncontrolled trade leads to three problems in the supplying countries. The first problem is that the rents from these illegal sales are rarely available for purposes of economic development. The second problem is environmental: Natural forests in Southeast Asia are grossly overexploited. Cambodia, Thailand and Vietnam have been obliged to impose logging bans. Myanmar, Indonesia and Malaysia have regulated logging, but these regulations are not adhered to and deforestation has continued, fuelled in particular by the demand from China. Environmental degradation hits the poor more than the population in general, as the poor are more likely to live on marginal or degraded lands and are more dependent upon use of natural resources for their livelihoods (BASS/STEELE 2006). The third problem is that this deforestation undermines the earning opportunities for people in the downstream industries. The causal chains vary. In Indonesia for example, export production of teak furniture has contributed substantially to the creation of jobs and incomes. The viability of this industry, however, is under threat because of depletion of the raw material supply. Moreover, Indonesia is competing in international markets with China and Vietnam who offer low prices, not just because of low wages, but because the furniture is made from illegal wood acquired at low prices. This un(der)controlled timber trade thus pulls the Southeast Asian furniture industry into a race to the bot- 
tom and undermines further income growth (LoEBis/SCHMitZ 2005).

\section{Food products}

The Chinese food market is undergoing rapid change. On the demand side, these transformations include rising consumer incomes, urbanisation, demographic changes (including an ageing population and increasing female participation rates) and the modernisation of retailing. These trends have already shifted food demand away from cereals and towards meat, fish, dairy and horticultural products (OECD $2005,64)$. On the supply side, there have also been significant structural transformations. Land use and output have shifted, with the land area devoted to cereals falling and cereal production roughly constant from 1990 through to 2003 (OECD 2005, 53). In contrast, output of fruit and vegetables, fish, meat and dairy have increased substantially. These changes are reflected in China's altered food trade profile. Exports of high-value and value-added products, including meat, fish and horticultural products have expanded rapidly, in line with China's comparative advantage in labour-intensive food production (LU 1998). China became a net food importer in 2004.

Alongside these structural changes, there has been a considerable liberalisation of food production, commercialisation and trade in China over this period. This has included a substantial decline in the importance of state procurement - now limited to grains - tariff reductions and a reduced, although still important, role for state trading enterprises. In this context, what are the opportunities and challenges opened up to the developing economies of East and Southeast Asia?

As is the case in many countries, food production and trade remain both regulated and politically sensitive. Up until recently, agricultural trade between most of the countries of SouthEast and East Asia (with the exception of Japan and Thailand) has been limited. ${ }^{7}$ In spite of having $20 \%$ of the world's population and $7 \%$ of the world's land, China was a net food exporter. A major factor in this has been the food self-sufficiency policy of the Chinese government. While analysts have been arguing for over a decade that China's comparative advantage lies in shifting agricultural production from grains, towards products which are less land intensive, more labour-intensive and less environmentally damaging (particularly with respect to water use), the Chinese government has remained committed to a policy of food self-sufficiency, which in practical terms means that domestic production of grain should meet at least $95 \%$ of domestic demand (FELLONI et al. 2003, 174). Since the mid1990 s, this policy has been pursued through a variety of policy measures, and its importance continues to be restated frequently, even though it has also been the source of vigorous policy debate at the highest level (SOLOT 2006, $44 \mathrm{f}$.). This policy effectively restricts the growth of agricultural trade by inhibiting specialisation according to comparative advantage.

So far, the direct impact of Chinese food exports has been felt more in relatively affluent countries rather than developing Asia. In the case of fresh fruit and vegetables, the major export markets for Chinese produce in 2004 were Japan, the United States, South Korea and Hong Kong. There is scope for Asian producers to increase access to the Chinese market. Although Chinese imports of fresh fruit and vegetables were only a quarter of the value of exports in 2004, Thailand, the Philippines and Vietnam were among the biggest exporters. Efficient producers will find space in a liberalised Chinese market, and even in areas where China has an overall comparative advantage, there will be opportunities. The countries taking these opportunities will also have to compete against other exporters, and bilateral trade agreements between China and Australia, Chile and New Zealand could open up the Chinese market to these efficient producers.

What is noticeable is the absence of the poorer countries in Southeast Asia from China's food trade (with the exception of Vietnam). Overall, Cambodia's exports of natural-resource-based and agricultural products reached $\$ 27.3$ mio.in 2005. Food products covered by the Early Harvest Program are a fraction of this, less than $\$ 1$ million. Chinese food exports were also very low. There is potential for increased trade in fruit and seafood products, but according to CHAN (2006) the major constraint is the limited capacity of the private sector, poor infrastructure, lack of an efficient marketing system, low productivity, inadequate extension services and the absence of a clear policy framework. When broader constraints on efficient business such as corruption, ineffective 
government and regulatory uncertainty are added to the mix, the prospects of competing with China are even more distant.

Nevertheless, substantial changes are taking place. With respect to the ASEAN countries (including the GMS countries) the potential for regional trade has been enhanced by the Early Harvest Program, introduced as part of the framework agreement on comprehensive economic cooperation between the ASEAN countries and China. This was intended to lead to zero tariff levels for agricultural trade between the ASEAN-6 countries by January 2006, and zero tariffs for the newer ASEAN countries (Cambodia, Laos, Myanmar and Vietnam) to be achieved for all agricultural products by 2010 at the latest (this information and the subsequent analysis relating to Cambodia is drawn from CHAN (2006). In this context, China could be both threat and opportunity.

Zero tariffs for food trade within the ASEAN region will benefit the countries that can combine effective regulatory and transport infrastructures with efficient production systems. Thailand and Vietnam are likely to prosper, as well as Malaysia. For the countries most in need of trade to promote growth in the rural economy, the obstacles are considerable. Initiatives to improve regional transport infrastructure are more likely to facilitate the import of Chinese produce to urban centres than to facilitate exports of agricultural products.

\section{Intermediate products}

In the words of ENRIGHT et al. $(2005,1)$ "China has become the last stop in a pan-Asian production system, in which capital goods and advanced components are imported from Japan, Korea and Taiwan; other inputs are imported from other Asian economies, mostly in Southeast Asia; and final assembly takes place in China". The implication is that the relationships are complementary: There is a synergy between China's globally-oriented assembly industries and suppliers of intermediate products across Asia.

\section{Deep integration and vertical trade}

In the course of the 1980s and 1990s, the importance of the Asian region for Chinese exports diminished while for imports it grew substantially (LALL/ALBALADEJO 2004). This is not just a trade story. A regional production system emerged. The development of this regional production system has become a focus of work on trade and regionalism. Regional policies that promote divisions of labour are seen as important drivers of productivity. This is reflected in the focus on "deep integration", defined by EvANs et al. $(2006,18)$ as "the creation of a 'common marketplace' across countries that permits enterprises to operate easily across national borders and to integrate production in regional value chains". While trade economists have been focusing on the institutional environment that might facilitate trade and regional divisions of labour, in East Asia de facto regionalisation has proceeded largely in advance of political initiatives for regional integration. ${ }^{8}$ The main characteristic of this $d e$ facto regional integration is the increasing trade in parts and components between countries. Some economists refer to this as "vertical trade" (Hummels et al. 1998, 81) - the incorporation of imported parts into products that are then exported.

What evidence is there that this type of regional production system has emerged?

- Intra-regional trade in East and Southeast Asia has been expanding much more rapidly than trade as a whole. The East Asian share of global trade increased threefold from 1975 to 2001, but the share of world trade accounted for by intra-regional trade in East Asia rose six-fold - from $1 \%$ of world trade to $6.5 \%$ (NG/YeATS 2003, 3). ${ }^{9}$

- The intensity of trade between countries in the region was much greater than would be predicted on the basis of relative size and distance, and this intensity has been increasing rapidly (NG/YEATS 2003, 20 ff.).

The high and rising level of intra-regional trade does not by itself prove that vertical specialisation or deep integration is present. However, the trade data tell us that:

- The export profiles of some countries increasingly match the import profiles of others. This complementarity is particularly strong for Hong Kong, Indonesia, Malaysia, the Philippines, Thailand and Taiwan (NG/ YeATs 2003, 24). This is reflected in the increasing importance of intra-industry trade and the decline of one-way trade in the re- 
gion. This is noted by FUKAO et al. $(2003,36)$ for trade as a whole, and by ANDO (2005, 16 f.) for machinery trade.

- Regional trade in parts and components, a key indicator of vertical trade, has been increasing. In 2001, $26 \%$ of East Asian interregional trade in manufactures (excluding chemicals) was in the 60 or so Standard International Trade Classification - Revision 2 (SITC) categories defined as parts and components (NG/YeATs 2003, 53). It is widely accepted that even these figures underestimate the true extent of trade in parts and components that are incorporated into products that fall into other product categories.
China is at the centre of this process. It substantially increased regional sourcing (i.e. the share of its total imports that come from within the East Asian region, excluding Japan), from $23 \%$ to $49.8 \%$ between 1985 and 2001, as can be seen in Tab. 3. At the same time, the importance of these Asian economies as destination markets for China reduces in the period, suggesting that China is the final point of a production system which exports products to the rest of the world. The countries that greatly increased the regional orientation of their exports in the period were Indonesia, Korea, the Philippines, and Taiwan China, although the increases in the second half of the period (1995-2001) were much less substantial than

Tab. 3: The share of intra-regional trade in East Asian imports and exports; 1985, 1995 and $2001(\%)$

\begin{tabular}{llll} 
East Asian Trader $(a)$ & \multicolumn{3}{l}{ Share of intra-regional trade in imports or exports (\%) } \\
\hline & 1985 & 1995 & 2001 \\
Exports & & & \\
China (43.1) (b) & 35.1 & 39.1 & 30.8 \\
Hong Kong, China (7.5) & 27.5 & 35.6 & 35.2 \\
Indonesia (4.2) & 9.9 & 25.0 & 27.2 \\
Korea (14.4) & 10.1 & 34.1 & 34.1 \\
Malaysia (3.3) & 38.1 & 43.5 & 42.0 \\
Philippines (2.9) & 17.5 & 23.5 & 34.4 \\
Singapore (3.8) & 35.1 & 43.8 & 44.9 \\
Taiwan, China (13.9) & 14.8 & 39.6 & 41.1 \\
Thailand (5.0) & 25.5 & 31.9 & 33.5 \\
Vietnam (1.2) & 48.4 & 31.0 & 29.3 \\
All Regional Exporters & $(c)$ & 37.5 & 35.0 \\
& 23.7 & & \\
Imports & & & 49.8 \\
China (43.1) & & 52.1 & 60.0 \\
Hong Kong, China (7.5) & 23.0 & 54.6 & 37.3 \\
Indonesia (4.2) & 46.8 & 25.8 & 25.8 \\
Korea (14.4) & 13.8 & 18.7 & 51.6 \\
Malaysia (3.3) & 13.4 & 45.2 & 37.1 \\
Philippines (2.9) & 44.4 & 33.6 & 43.5 \\
Singapore (3.8) & 34.1 & 42.2 & 31.4 \\
Taiwan, China (13.9) & 39.2 & 22.3 & 36.2 \\
Thailand (5.0) & 12.7 & 31.6 & 44.9 \\
Vietnam (1.2) & 33.4 & 68.1 & \\
All Regional Importers $(c)$ & 33.4 & 39.8 & \\
\hline
\end{tabular}

Notes: (a) includes all of the East Asian countries in the original table, except for those accounting for less than $1 \%$ of regional domestic product; (b) numbers in brackets refer to the share of these countries in regional domestic product; (c) includes Brunei, Lao DPR and Mongolia, no data is provided for Myanmar Source: adapted from NG/YEATs $(2003,14)$ 
in the first half. All of the countries listed in Tab. 3 increased the share of their total imports coming from the region in the period 19852001 .

One of the major factors driving these changes was the regional sourcing of intermediate products. This was particularly evident in the electronics industry. From 1990 to 2000, China increased its imports of electronics products from East and Southeast Asian countries from $12 \%$ to $62 \%$ of its total electronics imports (LALL et al. 2004, 417). All this suggests that countries in the region - with regard to intermediate products - tended to benefit from China's growth and export competitiveness.

This regional production system has been actively promoted through the trade policies of the Chinese government, giving the Chinese economy a distinctive dual structure. Duty exemptions for imports that are processed and reexported have created a dualistic trading structure of "processing trade" and "ordinary trade", as described by LEMOINE/ ÜNAL-KeSENCI (2004). The processing trade is an example of vertical trade, insofar as products are imported into the country, processed and re-exported. This trade is important in a range of sectors, including machinery, electronics, precision instruments, chemicals, apparel and shoes.

Trade policy cannot create something out of nothing. Regional integration has been promoted by companies in the region, notably Japanese firms, since the 1980s, and in the 1990s Korean and Taiwanese firms also invested heavily in Chinese production facilities. As a result, much of the processing trade is carried out through foreign affiliates (wholly owned foreign companies or joint ventures). Foreign affiliates were responsible for $45 \%$ of total exports from China in 1999, of which more than $80 \%$ were within the processing regime. LEMOINE/ ÜNAL-KESENCI $(2004,835)$ conclude that "a large proportion of China's trade thus corresponds to intrafirm trade between parent firms in Asian countries and their affiliates in the Mainland". There are however substantial sectoral variations.

\section{The future of the regional production system} As set out above, the emerging regional division of labour has established complementarities between China and the more advanced
East Asian economies. More than that, the success of China in global markets (particularly for machinery and electronics products) is best interpreted as the success of a broader regional production system. In the words of Lall/Albaladejo (2004, 1456): "China acts more as an engine of export growth than as a competitive threat to most of its neighbours". But they add: "It is difficult to predict if this will continue".

Indeed, relationships within this regional production system seem to be changing as Chinese firms move up the value chain and compete with producers of parts and components in other Asian countries. According to HALTMAIER et al. (2007) China is moving up the scale of technological intensity. Imported inputs continue to be important but the domestic content of Chinese exports is rising fast and the link between Chinese manufactured exports and imports is therefore weakening. Exports continue to be an engine of growth, but more for China's own industry than that of its neighbours; exports rely increasingly on domestically sourced rather than imported intermediate goods. According to the IMF (2007, $10 \mathrm{f}$.) "over the last two years, China's current account surplus has risen by nearly $5.5 \%$ of GDP, as import growth has begun to lag export growth by a significant margin. In particular (...) imports of intermediate goods have slowed considerably. Parts and components and semifinished goods accounted for almost half of the slow down in import growth between 2004 and 2005. In addition, there has been a significant slowdown in capital equipments imports, as domestic fixed asset investment continued to expand sharply in 2005 and 2006."

This signals substantial change. It suggests deepening integration within China, but lessening cross-border integration - and therefore a trend towards more competition and less complementarity. Future research will need to unpack this and differentiate between countries and sub-sectors. It could well be that complementarity will continue to exist where China's neighbours provide inputs which are very sophisticated and fast-changing but disappears fast in less sophisticated and mature inputs. If this is so, Japan and Korea (and far away Germany) are likely to benefit most from the Chinese export growth. But the picture is probably so differentiated and fast-changing that country-level analysis is not sufficient. 
It is however clear that China is occupying more of the skill-intensive and high-value spaces of the export-oriented value chains. The question is whether China will then slowly move out of low-end processing, leaving more space for other Asian countries. This may seem an unlikely scenario but given the pace of change within China, it is not premature to raise such questions. If such spaces are created, which Asian countries will benefit? Will it be the low-income Mekong countries, or other parts of Asia?

\section{Finished products}

The analysis of trade in intermediate products shows that up to recently, there has been a complementarity between China and the East and Southeast Asian economies. What is the story with respect to finished products, and in particular for manufactures? The rapid growth of Chinese manufactured exports has certainly led to anxieties. As LaLL/Albaladejo (2004, 1457) suggest "China's export surge has raised grave concerns in the region. While some of the apocalyptic predictions are overdone, it is possible that rapid export growth by such a massive entrant will adversely affect export growth by its neighbors".

As well as the indirect effects arising from competition in third markets, highlighted here by Lall and Albaladejo, there are also the direct effects that arise from trade between China and other Asian countries. These effects need not be negative. The benefits for consumers in the global economy, including Asia, from access to cheap Chinese manufactures is often overlooked. It is particularly important in countries that have limited manufacturing sectors. In fact, exporters of energy and raw materials may gain a double benefit from China's rise: increasing prices for their exports and decreasing prices for their imports of manufactures. Given the rise of intra-regional trade, and the rapid growth of China's exports to the rest of the world, a critical question for the Asian economies is the extent to which China is a large potential market for finished goods or a source of competition in both the domestic markets of Asian countries and in third markets.

\section{Direct effects}

The first thing to note is that the data do not support the idea that China is a massive net exporter of manufactures to countries in Asia that are potential competitors as producers of manufactures. On the contrary, with the exception of Hong Kong (which is a special case), and Singapore, these countries had trade surpluses with China in manufactures in 2000 (see Tab. 4).

Second, these figures incorporate trade in components, for which it is known that China was a significant net importer. This can be stripped out at the sectoral level by using data on intraAsian trade that distinguishes between finished products and parts and components. In the case of electronics, the same countries listed in Tab. 4 had a total trade surplus with China in finished electronics products of $\$ 5.8$ billion (Lall/AlbaladeJo 2003, 50).

Once again, however, there are significant differences between the countries of the Greater

Tab. 4: China's trade in manufactures with East Asian economies in 2000 (\$ billion)

\begin{tabular}{llcc} 
Countries $^{(a)}$ & Exports from China & Imports into China & Balance $^{(b)}$ \\
\hline Korea & 8.54 & 22.03 & -13.48 \\
Taiwan & 4.25 & 23.25 & -19.00 \\
Singapore & 5.35 & 4.86 & 0.49 \\
Indonesia & 2.29 & 2.37 & 0.09 \\
Malaysia & 2.14 & 4.64 & -2.49 \\
Philippines & 1.27 & 1.43 & -0.16 \\
Thailand & 1.93 & 3.40 & -1.47 \\
\hline
\end{tabular}

Note: (a) Data for Hong Kong have been excluded from this table. The data for the other countries in the table could be distorted by entrepot trade, with exports from China more underreported (as they pass through Hong Kong) than imports. (b) A negative figure indicates a Chinese trade deficit. 
Mekong Subregion (GMS) and the more developed countries of the region (see Tab. 5). This compares the four less developed GMS countries with South Korea and Thailand. All of these countries had significant balance of trade deficits in garment categories 61 and 62 (apparel and clothing, both knitted and crocheted and not knitted and crocheted). In the case of electrical and mechanical machinery, the four poorer GMS countries also ran deficits with China, but Thailand and Korea ran surpluses amounting to billions of dollars (including parts and components), that more than offset the garments deficits. Cambodia, Lao and Myanmar are exporting negligible amounts in these sectors that are so important for global and regional trade. Vietnam, however, is importing both garments and machinery from China. It is exporting to the rest of the world, and it is likely that some of these imports from China are incorporated into goods that are subsequently exported.

In future, China might become a more significant market for Asian exporters of finished products. This would be particularly the case if domestic savings rates fall in China and the economy becomes less dependent on exports as a driver of economic growth. This would tend to increase demand for imported products. However, any changes will take some time to take effect.

\section{Indirect effects}

What are the indirect effects of China's manufacturing export boom? China has greatly expanded its share of the global market for manufactured products in the 1990s, when its man- ufactured exports grew by $17 \%$ per annum. More important, its share of total developing country manufactured exports doubled, from approximately $10 \%$ to approximately $20 \%$. China's rising share of the world market was particularly pronounced for low technology products, where it grew from $4.9 \%$ to $12 \%$ (Lall/AlbaladeJo 2004, 1450). ${ }^{10}$ These are the products that low-income countries in Asia are most likely to export.

Is there any evidence that China's growth was at the expense of other countries in the region? For the 1990s, the answer would have to be no. For manufactures as a whole, the seven countries listed in Tab. 4 all managed to increase their share of global manufactured exports. Without China, their shares might have increased more rapidly, but in this period the dynamism of the Asian economies and their global competitiveness was sufficient for all of these countries to gain ground. If China did take market shares away from these countries in certain product lines, they were able to compensate by expanding exports of other products. The losers were elsewhere in the global economy. China's exports of manufactures grew more rapidly than those of the rest of East Asia, and so China increased its share of total (East) Asian exports. However, total East Asian exports also rose, so the absolute values of non-Chinese exports from East Asia also rose.

But how long can this continue? WONG/CHAN (2002, $87 \mathrm{f}$.) emphasise the potential threat from Chinese competition to the ASEAN-4 countries (Indonesia, Malaysia, Philippines and Thai-

Tab. 5: China's trade in selected manufactures with selected Asian economies in 2004 (US\$ millions)

Garments (HS 2002 categories 61 and 62) Elect. and mech. machinery (HS 2002 categories 84 and 85)

\begin{tabular}{|c|c|c|c|c|c|c|}
\hline Partner countries & $\begin{array}{l}\text { Export } \\
\text { from China }\end{array}$ & $\begin{array}{l}\text { Imports } \\
\text { into China }\end{array}$ & Balance & $\begin{array}{l}\text { Exports } \\
\text { from China }\end{array}$ & $\begin{array}{l}\text { Imports } \\
\text { into China }\end{array}$ & Balance \\
\hline Cambodia & 11 & 1 & 10 & 38 & 0 & 38 \\
\hline Lao DPR & 3 & $0^{(a)}$ & 3 & 50 & 0 & 50 \\
\hline Myanmar & 11 & 0 & 11 & 290 & 0 & 290 \\
\hline Vietnam & 88 & 5 & 83 & 766 & 115 & 651 \\
\hline S. Korea & 2,707 & 77 & 2,630 & 9525 & 25,470 & $-15,946$ \\
\hline Thailand & 25 & 6 & 19 & 2,538 & 5,716 & $-3,178$ \\
\hline
\end{tabular}

Note: (a) any sum less than $\$ 1$ million is registered as zero Source: Comtrade. China as reporting country 
land), suggesting that China's WTO accession will exacerbate the problem. The key factors affecting the likely future outcome are: (i) the extent to which global markets for the products in question will continue to expand (sustaining opportunities for all), and (ii) the speed at which China's own rapid growth will undermine its competitiveness in low-skilled manufacturing.

In the case of low technology products in particular, China did not undermine exports from the ASEAN countries. Korea and Taiwan did see their world market shares for low technology manufactures decline in the 1990s, but this should be seen as a result of upgrading and hollowing out of low-wage manufacturing. This fall is what one would expect. Not only were these countries moving into more sophisticated sectors of manufacturing where their rising labour costs were less of a handicap, but they were also hollowing out their manufacturing, transferring production to other Asian economies (for example, to China and Indonesia in the case of footwear) but continuing to occupy roles in the industry as marketers, designers and producers of components. This is one of the tendencies that have driven the regional division of labour in Asia and the rapidly rising trade in intermediate goods. Korea and Taiwan are not so much losing out to China as repositioning themselves within global production networks. ${ }^{11}$ The manufacturing exporters in the region that might have been under threat - Malaysia, Thailand, Indonesia and the Philippines - all saw their shares of global low-technology manufactured exports rise. The big losers have been elsewhere in the global economy. In footwear, for example, those big losers so far have been not China's East Asian competitors but countries like Brazil. ${ }^{12}$

Even in the garments industry, where the continuing strong growth of Chinese exports after 2000 raised the prospect of increasing competition for other Asian producers, particularly following the January 2005 elimination of the Multifibre Arrangement (KAPLINSKY et al. 2007), pessimistic expectations have so far proved to be unfounded, on the whole. Bangladesh, Cambodia and Vietnam have all continued to expand garment exports, albeit at the cost of restructuring. While part of this performance may have been caused by temporary restrictions on imports of Chinese garments and textiles to Europe and the United States in the second half of 2005 , these countries do seem to be able to compete with China or find niches where Chinese competition is less intense. CHAPONNIÈRE et al. (2007, 13 ff.) argue that even in sectors other than textiles and clothing, there is potential for not competing head-to-head with China, and that Vietnam has managed to do this.

\section{Competition for foreign direct investment (FDI)}

Foreign direct investment (FDI) has been a major driver in the process of East Asian economic integration. Over the past 20 years, much of this FDI has come from within the region, particularly from Japan (for an analysis of the changing nature of objectives of Japanese FDI in the region see HAYTER/EDGINGTON 2004, 11). More recently, other economies in the region have contributed to the formation of regional production networks through FDI in the region: "The erosion of Japan's comparative advantage in manufacturing and the global trend towards 'unbundling' of manufacture processes led Japanese firms to 'unbundle' their manufacturing process and offshore labour-intensive stages of production to nearby East Asian nations. This 'hollowing out' of the Japanese economy started the development of 'Factory Asia' and the hollowing out of Taiwan, Korea, Singapore and Hong Kong extended it" (BALDWIN 2006, 1489).

The role of Hong Kong in the development of China and its increasing specialisation in trade, market linkages and management of manufacturing operations in China has been highlighted by ENRIGHT et al. (2005) and CHIU/WONG (2002). Similarly, analyses of the transformation of labour-intensive industries in South Korea and Taiwan have pointed to the transfer of labour-intensive production from these countries to lower-wage economies in the region (LiM 1994; HsIng 1998). While some of it is due to relocation of production by Korean and Taiwanese companies, the sourcing and investment decisions of global companies also play an important role. EICHENGREEN/TONG (2005, 21) conclude the analysis of competition for FDI in the region as follows: "Thus, from our results it would appear that the hollowing-out phenomenon in Korea reflects not so much the diversion of Korea's own investment toward China as the diversion of inward investment toward lower labor-cost economies." 
Therefore, the issue of competition for investment still needs to be addressed - as China is not the only low wage economy in the region. Various studies have shown that the massive inflows of FDI into China witnessed in the 1990s have not led directly to declines in FDI in other parts of Asia. While China's share of total Asian FDI rose, the absolute levels of FDI going to other Asian countries continue to rise. An econometric analysis by CHANTASASAWAT et al. (2004), which covered the period 1985 to 2001 , concluded that China has a positive effect on the level of FDI in other Asian economies. It also concluded, importantly, that policy variables such as rates of corporation tax and trade openness were more important determinants of FDI flows than the "China effect" (Chantasasawat et al. 2004, 24 f.). This implies that other Asian economies should worry more about the determinants of their competitiveness that are under their own control rather than be focused on potential threats from China.

It is important to recognise the limitations of such studies which focus on the aggregate regional effects. As stressed by WEISS (2007), they assess whether total FDI to the region is influenced positively or negatively by FDI to China, rather than looking at individual country effects. These regional versus individual country effects are examined by Wang/Wei/Liu ("Does China Rival its Neighbouring Economies for Inward FDI?" - referred to by WEISS 2007, 12). The main conclusion is no diversion effect for the region in aggregate but significant variations between countries. Negative diversionary effects are said to exist in some specifications for Korea, Taiwan, Malaysia, and Indonesia. There are, however, problems with the reliability and comparability of FDI data for China and other countries in the region. With these data problems in mind, WEISS (2007, 13) concludes "FDI diversion, whilst it may exist, has not been found conclusively in recent studies".

\section{Conclusion}

Over the last 30 years, changes in the East and Southeast Asian region have been fast and deep. They remind us that the past is not necessarily a good guide to the future. But understanding the past and present is a necessary starting point. We have shown that China's sourcing of intermediate products from the East and Southeast Asian region has occurred on a significant scale, has been promoted by government policy, and has taken the form - in some sectors more than others - of intra-firm trade. China's own growth has thus spilled over into other Asian countries. The question is which countries are part of this regional production system and have thus been able to take advantage of the opportunities to create jobs and raise productivity? Scanning the sources referred to above suggests that one can distinguish between three groups of countries:

- Countries which are major suppliers of intermediate products: notably Korea, Taiwan Province and Singapore. They have trade surpluses and are critical for the supply of parts and components to the Chinese economy.

- Countries which are lesser suppliers: the ASEAN-4 countries: Malaysia, Philippines, Indonesia and Thailand. Vietnam is similar to these countries in some respects.

- Countries which play little or no role in this regional production system, notably the poorer ASEAN countries such as Laos, Cambodia and Myanmar, and most countries in South Asia and Central Asia.

All this reinforces the idea of a core and a periphery to China in Asia put forward by EICHENGREEN (2006). The problem for the GMS countries is not only do they trade relatively little with China, but the trade itself may undermine long-term growth prospects.In contrast, the emergence of a regional production system has created enormous opportunities for China's more advanced neighbours. The big questions for the future are:

- Is the existing regional production system, in which China relies heavily on intermediate products from some Asian countries, likely to continue? We have seen that the overall reliance on imported inputs from other Asian countries has begun to decrease but a more differentiated analysis is needed to judge where new threats and opportunities arise.

- Can countries in the periphery, which are not deeply integrated into this regional production system, connect more closely? In which sectors do they want to connect more closely and how can policy contribute to greater con- 
nectivity? These questions are often difficult to address because the status quo of trade links with China is not clear. Casual observations and references in the press indicate that informal trade is taking place on a significant scale. Mapping more systematically the trade links, including the network of traders, would be an important contribution to informed policy making.

With regard to competition in third markets, the main concern is that China will displace exports of labour intensive products from other Asian developing countries and depress prices leading to deterioration in the terms of trade. JENKINS/EDWARDS (2004) examined whether this has in fact happened, concentrating on those products which are most likely to affect the Asian poor, namely labour intensive agricultural products and manufactures. They conclude that over the period 1990-2001, competition with other Asian exporters has increased. They emphasise, however, that future analysis needs to be carried out at a more disaggregated level. We indicated above that the pessimistic expectations have not been confirmed so far but endorse the need for more detailed investigation.

The general points emerging from this analysis are that participating in the global economy provides enormous opportunities, that China's growth augments these opportunities, but that China's participation risks pulling other countries into a race to the bottom. The big challenge for policy makers in the poorer Asian countries is improving connectivity with the Chinese growth engine and making their own growth sustainable. 13

\section{Notes}

1 This is a shortened and revised version of "China: Its Impact on the Developing Asian Economies", IDS Working Paper No 295, 2007. We are grateful for comments from the DFID China Office, Tilman Altenburg, Jing $G u$ and an anonymous referee.

2 In 2004, India's economy was one third the size of China's and its trade openness (exports+imports as a percentage of GDP) was $40 \%$ compared to $65 \%$ in China (World Development Indicators database). As a result, China's global footprint was 4.5 times greater than India's.

3 For analyses of the impact of China on Sub-Saharan Africa and Latin America, see KAPLINSKY et al. 2007 and Jenkins/Dussel Peters 2007.
4 The Greater Mekong Subregion includes Thailand, Yunnan Province and the Guangxi Zhuang Autonomous Region as well as Cambodia, Laos [this name is used as an alternative to Lao DPR], Myanmar and Vietnam. Here, the focus will be on the latter four countries.

5 Presenting the trade data from the perspective of China confirms this picture. For details, see HUMPHREY/ SCHMITZ 2007.

6 The World Bank's Global Economic Prospects 2005 calculates the cost to Pakistan of an increase in oil prices of $\$ 10$ a barrel to be equivalent to $1.38 \%$ of GDP.

7 The main exception is palm oil. China is the largest export destination for the palm oil industry of Malaysia and also a major destination for Indonesia.

8 This is not to say that regionalism initiatives are not proceeding apace. They are. BALDWIN (2006, 1489) argues that "Regionalism played almost no role in fostering East Asian trade in the 1985-2000 period", but he goes on to describe a "noodle bowl" of recent regional trade agreements and initiatives.

9 The countries included in this calculation are: Brunei, Cambodia, China, Republic of Korea, Hong Kong, Indonesia, Lao PDR, Malaysia, Mongolia, Philippines, Singapore, Taiwan (China), Thailand, and Vietnam.

10 The low technology manufactures category includes textile fabrics, clothing, headgear, footwear, leather manufactures, travel goods, pottery, simple metal parts/structures, furniture, jewellery, toys and plastic products (LALL/ALBALADEJO 2003, 57).

11 The rise of these global production networks is now increasingly recognised by mainstream economists, as evidenced by the discussion of global production networks in the Global Economic Prospects 2005 (World Bank 2005).

12 The impact of Chinese competition on Brazilian firms in the footwear industry has been documented by SCHMiTZ (1999).

13 Ways of meeting these policy challenges are discussed in HuMPHREY/SCHMITZ 2007.

\section{Literature}

ANDo, M. (2005): Fragmentation and vertical intra-industry trade in East Asia. Claremont Regional Integration Workshop with Particular Reference to Asia, Claremont McKenna College, U.S.A, February. Internet: http://lowe.claremontmckenna.edu/events/pdf/AndoPaper022505.pdf (Dec. 2005).

Asian Development Bank (2005): Key indicators 2005. Part II: Poverty in Asia: Estimates and projections. Manila. (Asian Development Bank, Internet: http://www.adb.org/Documents/Books/Key_Indicators/2005/).

BALDWIN, R. (2006): Multilateralising regionalism: Spaghetti bowls as building blocs on the path to global free-trade. In: The World Economy, (29)11, 1451-1518. 
BAss, S./SteEle, P. (2006): Managing the environment for development and to sustain pro-poor growth. In: IDS Bulletin, (37)3, 7-16.

Chaponnière, J.-R./Cling, J.-P./ Zhou, B.(2007): Vietnam following in China's footsteps: The third wave of emerging Asian economies. Helsinki. (Paper presented at 'WIDER Conference on Southern Engines of Global Growth: China, India, Brazil, and South Africa', Helsinki, September 2007).

Chan, S. (2006): The potential impact of China on Cambodia's agriculture. Chiang Mai. (Paper presented at the conference 'China in Mainland Southeast Asia: Flying with the Dragon?', October 2006).

Chantasasawat, B./Fung, K.C./IIzaKa, H./SiU, A. (2004): The giant sucking sound: Is China diverting foreign direct investments from other Asian economies? Seoul. (6th Asian Economic Panel Meeting, Seoul, October 2003, Internet: http://econ.ucsc.edu/faculty/workingpapers/fung2.pdf, Dec. 2005).

ChIU, S.W.K./Wong, K.-C. (2002): The hollowing out of Hong Kong electronics: Organizational inertia and industrial restructuring in the 1990s. Hong Kong. (Paper presented at the Workshop on Global Value Chains, Rockport, MA, Hong Kong, Department of Sociology, The Chinese University of Hong Kong).

Chunquan, Z./TaYlor, R./Guoqiang, F. (2004): China's wood market. Trade and the environment. Marrickville NSW.

CoxHEAD, I. (2007): A new resource curse? Impacts of China's boom on comparative advantage and resource dependence in Southeast Asia. In: World Development, (35)7, 1099-1119.

EICHENGReEn, B./Tong, H. (2005): Is China's FDI coming at the expense of other countries? Cambridge MA. (National Bureau of Economic Research, Working Paper 11335).

Eichengreen, B. (2006): China, Asia and the world economy: The implications of an emerging Asia core and periphery. In: China \& World Economy, (14)3, 1-18.

Enright, M.,/ScotT, E./ Chang, K. (2005): Regional power house: The Greater Pearl River Delta and the rise of China. Singapore.

Evans, D./Kaplinsky, R./Robinson, S. (2006): Deep and shallow integration in Asia: towards a holistic account. In: IDS Bulletin, (37)1, 12-22.

Felloni, F./ Gilbert, J./WAhl, T./WANDSChNEIDER, P. (2003): Trade policy, biotechnology and grain self-sufficiency in China. In: Agricultural Economics, (28)3, 173-186.

FuKaO, K./Ishido, H./ITo, K. (2003): Vertical intra-industry trade and foreign direct investment in East Asia. Tokyo. (Research Institute of Economy, Trade and Industry, RIETI Discussion Paper, Internet: http://www. rieti.go.jp/jp/publications/dp/03e001.pdf, Dec. 2005).

Global Witness (2005): A choice for China: Ending the destruction of Burma's northern frontier forests. A Briefing Document. London. (Internet: http://www. globalwitness.org/reports/, Oct. 2006).
Gottschalk, R./ Prates, D. (2006): East Asia's growing demand for primary commodities: Macro economic challenges for Latin America. Geneva. (UNCTAD, G24 Discussion Paper Series).

Haltmaier, J.T./Ahmed, S./COUlibaly, B./KnipPenBERG, R./LEDUC, S./MARAZZI, M./Wilson, B.A.(2007): The role of China in Asia: Engine, conduit, or steamroller? Helsinki. (Paper presented at 'WIDER Conference on Southern Engines of Global Growth: China, India, Brazil, and South Africa', September 2007).

HAYTER, R./EdGington, D.(2004): Flying geese in Asia: The impacts of Japanese MNCs as a source of industrial learning. In: Tijdschrift voor Economische en Sociale Geografie, (95)1, 3-26.

Hsing, Y. (1998) Making capitalism in China. The Taiwan connection. New York, Oxford.

HumphreY, J./Schmitz, H. (2007): China - its impact on the developing Asian economies. Brighton. (IDS Working Paper, 295).

Hummels, D./RAPOPORT, D./YI, K.-M. (1998): Vertical specialisation and the changing nature of world trade. In: Federal Reserve Bank of New York Economic Policy Review, (4)2, 79-99.

IMF (2007): Regional Economic Outlook: Asia and Pacific. World Economic and Financial Surveys. Washington.

INDRAWATI, S.M. (2006): Unleashing poverty reduction in emerging Asia. Asia 2015: Promoting growth, ending poverty. London. (Intertnet:: http://www.asia2015conference.org/speeches.htm, March 2006).

Jenkins, R.J./Dussel Peters, E. (2007): The impact of China on Latin America and the Caribbean. Brighton. (IDS Working Paper 281).

JEnkins, R./Edwards, C. (2004): How does China's growth affect poverty reduction in Asia and Latin America? Norwich. (Overseas Development Group, University of East Anglia, Report to DFID, mimeo).

JoHnson, S. (2002): Documenting the undocumented. In:Tropical Forest Update, (12)1, 6-9.

KAPlinsky, R./McCoRMICK, D./ MORRIS, M. (2007): The Impact of China on Sub-Saharan Africa. Brighton. (IDS Working Paper).

Lall, S./ Albaladejo, M. (2003): China's manufactured export surge: The competitive implications for East Asia. Oxford. (Queen Elizabeth House. Report prepared for the East Asia Department of the World Bank).

Lall, S./ Albaladejo, M. (2004): China's competitive performance: A threat to East Asian manufactured exports? In: World Development, (32)9, 1441-1466.

Lall, S./ AlbaladeJo, M./ Zhang, J. (2004): Mapping fragmentation: Electronics and automobiles in East Asia and Latin America. In: Oxford Development Studies, (32)3, 407-432.

LEMOINE, F./ ÜNAL-KeSENCI, D. (2004): Assembly trade and technology transfer: The case of China. In: World Development, (32)5, 829-850.

LIM, J.D. (1994): Restructuring of the footwear industry and the industrial adjustment of the Pusan economy. In: Environment and Planning A, (26)4, 567-581. 
LOEBIS, L./SCHMITZ, H. (2005): Java furniture makers: Globalisation winners or losers? In: Development in Practice, (15)3-4, 514-521.

LU, F. (1998): Grain versus food: A hidden issue in China's food policy debate. In: World Development, (26)9, 1641-1652.

MitsuHASHI, K. (2001): The furniture value chain from Thailand to Japan. Brighton. (Institute of Development Studies, mimeo).

NG, F./YeAts, A. (2003): Major trade trends in East Asia: What are their implications for regional cooperation and growth? Washington D.C. (World Bank Policy Research Working Paper 3084, Internet:http://econ. worldbank. org/view.php?typ e=5\&id=2787, January 2005).

OECD (2005): OECD review of agricultural policies: China. Paris.

Pech, S./ SunAda, K. (2006): China natural resources demand: Opportunities and challenges for Mekong Sub-Region. Chiang Mai. (Paper presented at a conference 'China in Mainland Southeast Asia: Flying with the Dragon?', October 2006).

Schmitz, H. (1999): Global competition and local cooperation: Success and failure in the Sinos Valley, Brazil. In: World Development, (27)9, 1627-1650.
Solot, I. (2006): The Chinese agricultural policy trilemma. In: Perspectives, (7)1, 36-46.

UMBACH, F. (2005): Global energy security and its geopolitical consequences to EU-Asian Relations. In: van der Geest, W. (Ed.): The European Union's strategic interests in East Asia. Vol. 2: Expert analyses of East Asian Cooperation, China's Role and EU policy. Brussels, Bologna, 194-223. (European Institute for Asian Studies and NOMISMA, Internet: http://www.asia 2015conference.org/).

WeIss, J. (2007): China and its neighbours: Patterns of trade and investment', Bradford. (University of Bradford, mimeo - revised May version).

White, A./ Sun X./ Canby, K./ Xu, J./ Barr, C./ Katsigris, E./ Bull, G./ Cossalter, C./ Nilsson, S. (2006): China and the global market for forest products: Transforming trade to benefit forests and livelihoods. Washington D.C. (Internet: www.forest-trends. org).

Wong, J./ CHAN, S. (2002): China's emergence as a global manufacturing centre: Implications for ASEAN. In: Asia Pacific Business Review, (9)1, 79-94.

World Bank (2005): Global economic prospects 2005. Washington D.C. 